\title{
1
}

\section{Pater as Professional Classicist}

\author{
Isobel Hurst
}

The expansion of classical studies in the late nineteenth century opened up increasingly diverse perspectives on antiquity, establishing the study of art history, archaeology, and anthropology as alternatives to traditional philology. Christopher Stray describes the development of Classics in English schools and universities 'from classical dominance to a pluralized field of specialisms', taking place at the same time as a transition from 'an earlier world of gentlemanly amateur scholars to that of professional researchers'. ${ }^{1}$ Working both within the academy and in the London literary world, Pater made a significant contribution to changes in the discipline by supplementing literary, historical, and philosophical texts with lectures on art and archaeology, and by introducing students of the ancient world to the mythic and ritual contexts of their set books.

Pater entered the Queen's College, Oxford, in 1858 with an exhibition from King's School, Canterbury. His tutor was W. W. Capes of Queen's College, and he made friends with Ingram Bywater (later Regius professor of Greek at Oxford). After 1850, an Oxford Classics degree was in two parts: in addition to the existing preliminary examination, Responsions (usually taken in the second term), a new examination, Moderations ('Mods'), marked the transition from a focus on language and literature in the first five terms, to ancient history and philosophy (particularly Plato and Aristotle) for the rest of the course ('Greats'). ${ }^{2}$ In Responsions, candidates had to show knowledge of one Latin and one Greek author, 'the chief object being to ascertain that the principles of these languages are well understood', and to undertake a translation from English into Latin and a paper of grammatical questions as well as several mathematics papers. For Mods the minimum 
requirements were the four Gospels in Greek (a relic of Oxford's role in preparing candidates for the Anglican ministry), one Greek and one Latin author (one poet and one orator), and translation, grammar, and mathematics as for Responsions. Candidates for honours were recommended to study Homer, Virgil, Demosthenes, and Cicero; the highest honours required a Logic examination and offered opportunities for demonstrating skill in both verse composition and 'elegant and accurate' translation into Latin and Greek. ${ }^{3}$ Options to be studied for Responsions were: five books of Homer, any two plays by Greek dramatists, two or three books of Herodotus, two books of Thucydides, four books of Xenophon's Anabasis; a portion of one Latin author such as Virgil's Georgics, or the Eclogues plus three books of the Aeneid, or five books of the Aeneid, or portions of Terence, Cicero, Sallust, Livy, or Horace. ${ }^{4}$ For Mods, the required portion of Homer was six books, the number of plays three, and the other Greek options Pindar and Demosthenes. The Latin authors were Terence, Cicero, Virgil, Horace, and Juvenal. Candidates for honours were required to offer larger portions of each author-twelve books of Homer and six tragedies-and might offer a wider range of authors including Plautus, Terence, Lucretius, and Tacitus. ${ }^{5}$ For Greats the classical requirements for 'passmen' included studying one philosopher and one historian (Greek or Latin) and translating passages from the set texts into English. Honours candidates faced much more demanding requirements: 'the Greek and Latin Languages, Greek and Roman History, Chronology, Geography, Antiquities; Rhetoric and Poetics; Moral and Political Philosophy. These subjects may be illustrated by Modern Authors.' Translation, questions, and composition in Greek and Latin were compulsory. Logic (mainly Aristotle) was required for first- or second-class degrees, and had 'great weight in the distribution of Honours'. ${ }^{6}$

Pater's interests seem to have centred on philosophy and logic: Edmund Gosse observes that as an undergraduate Pater did not demonstrate a 'partiality for pure literature or plastic art' but was 'fascinated mainly by the study of logic and metaphysic, which were his pastimes, while the laborious business of classical scholarship occupied all but his leisure moments'. ${ }^{7}$ Frank Turner notes that Pater 'read deeply in English empiricist philosophy and psychology as well as Hegelian literature' 
in the 1860 s, and was 'thoroughly receptive to the spirit of relativism in philosophy and religion' ${ }^{8} \mathrm{He}$ had a good knowledge of German, and read contemporary German philosophers. An essay Pater had written for Benjamin Jowett, then Regius professor of Greek, impressed Jowett so much that he offered to coach him without payment. ${ }^{9}$ Jowett's style of coaching, in which a close relationship between tutor and students was designed to improve academic standards, was crucial to the development of Oxford's tutorial system. Jowett also maintained connections between the university and the wider world, with weekend parties that brought Oxford together with 'poets and Prime Ministers'. ${ }^{10}$ Pater valued Jowett's teaching and his 'great originality as a writer and thinker':

Like many others I received much kindness and help from him when I was reading for my degree (1860 to 1862 ) and afterwards. A large number of hours in every week of Term-time must have been spent in the private teaching of undergraduates, not of his own College, over and above his lectures, which of course were open to all. They found him a very encouraging but really critical judge of their work-essays, and the like,-listening from 7.30-10.30 to a pupil, or a pair of pupils, for half an hour in turn. Of course many availed themselves of the, I believe, unprecedented offer to receive exercises in Greek or English in this way, and on the part of one whose fame among the youth, though he was then something of a recluse, was already established. ${ }^{11}$

Pater's wide reading and innovative approach to the classics exceeded the narrow confines of the university's requirements: 'It is not, it never has been, the imaginative men - the men of genius — who take the highest honours at a University', claims Thomas Wright. ${ }^{12}$ Pater’s achievement of a second in Literae Humaniores in 1862 does not suggest a deficiency in his knowledge of Latin and Greek language and literature, but rather that his scholarly interests did not align well with the Greats curriculum of his time. Helen Law concludes that Pater was 'thoroughly at home in Greek literature', and able to make effective and artistic use of his accurate translations from Greek texts. ${ }^{13}$ Henry Nettleship, awarded a second in 1861, went 
on to become Corpus Christi professor of Latin at Oxford. The poet and classical scholar A. E. Housman, later professor of Latin at University College London and Kennedy professor of Latin at Cambridge, failed the honours examinations for Greats in 1881. Housman excelled in the literature and language papers set for Mods, and devoted himself to the study of Propertius rather than the ancient history and philosophy of the Greats curriculum. ${ }^{14}$ A. C. Benson suggests that Pater was 'no scholar, in the technical sense of the word' but 'answered rather to Lord Macaulay’s definition of a scholar, one who read Plato with his feet on the fender. He . . . was on the look-out for quality rather than definite facts'. ${ }^{15}$ The 'technical' understanding of classical philology to which Benson alludes was perhaps more associated with Cambridge than with Oxford in this period. For philologists, the justification for placing Latin and Greek at the centre of the curriculum was that students would sharpen their intellects by solving the linguistic equivalent of problems in mathematics: Stray notes that the Cambridge model of close analysis of texts was influenced by the 'relationship between classics and mathematics' in the curriculum. ${ }^{16}$ Nettleship commented that the Oxford degree was not well adapted to modern classical scholarship: he spent four months in 1865 at a German university, and found that while he knew how 'to read the classics, to translate them on paper, to think and talk about them, to write essays on them', he had learned 'next to nothing' of 'the higher philology, of the principles and methods of textual criticism'. ${ }^{17}$

Pater became a private tutor, before being elected to the first non-clerical fellowship in Classics at Brasenose College in 1864. Gosse describes Pater's life as a college lecturer as 'quiet, cloistered, and laborious' ${ }^{18}$ While some critics have argued that Pater did not take his academic career seriously, William Shuter observes that 'the evidence indicates that Pater conscientiously performed the functions of a don, preparing young men for Moderations and the Final School in Greats, delivering college or catechetical lectures as well as university lectures and meeting with undergraduates in tutorials to review their essays' ${ }^{19}$ Lesley Higgins lists some of the essay themes 
that Gerard Manley Hopkins wrote for his tutorials with Pater, mostly concerned with Plato or with ethical questions. ${ }^{20}$ Pater took pains with the essays submitted to him; most tutors listened while students read essays aloud and made criticisms 'as they arise in the mind, without previous preparation', but Pater 'had the essays shown up to him, [and] scrutinised them carefully, even pencilling comments upon the page; and then, in an interview, he gave careful verdicts as to style and arrangement, and made many effective and practical suggestions ${ }^{\prime} .{ }^{21}$ Wright suggests that Pater's focus on prose style and biographical writing could be attributed to Jowett's influence. ${ }^{22}$

Pater's approach to scholarship could prove disconcerting for those students who merely wanted to pass their examinations. Humphry Ward notes that the Brasenose undergraduates reading Greats in 1867 expected their lectures to consist of 'the old formulae about Thales and some references to Aristotle that we could take down in our books and use for the Schools'. Instead Pater gave 'a quickly delivered discourse, rather Comtian, on the Dogmatic and Historical methods: quite new to me, and worse than new to some others' ${ }^{23}$ Shuter acknowledges that Pater's published lectures lack 'the systematic rigor that would recommend [them] to undergraduates preparing for Greats', although he does treat 'many of the subjects on which candidates were asked to write'. ${ }^{24}$ Pater's reading of ancient philosophy in relation to modern literature and philosophy is consistent with the comparative approach encouraged in students of Greats. Shuter notes that the 'remarkably ambitious school of Literae Humaniores' was 'designed not only to introduce young men to certain designated works of philosophy and history by the principal Greek and Roman authors but to train them to think critically about philosophic and ethical questions and to relate historically earlier to historically later stages of thought'. He demonstrates that Pater's 'published writings reflect, or have their origin in, the intellectual culture of which Greats was the centerpiece and the formal embodiment' ${ }^{\prime 25}$ The feature of Greats that made the course such a useful training for cultural critics such as Matthew Arnold and Oscar Wilde was that they were encouraged to compare and contrast texts, philosophical arguments, and historical examples from ancient Greece and Rome with 
'modern historical scholarship and to contemporary institutions and problems', to notice 'parallels between the ancient and modern worlds and to examine their validity'. ${ }^{26}$

A system of 'combined or university lectures', open to undergraduates from all colleges, developed in the 1870s. This new system 'altered the style of tutorial teaching, freeing the tutor from the reading of an examination text and permitting him to organize his lectures by a historical period or subject in which he had a special interest' ${ }^{27}$ Pater offered thirty-eight lecture courses in twenty years, mostly on Plato, Aristotle, and other Greats texts. He also lectured on Greek art, and was one of the first Oxford academics to address the recent findings of archaeologists such as Heinrich Schliemann (Mycenae) and Charles Newton (Cnidus). ${ }^{28}$ His 'coupling of ancient literature, archaeology, myth and cultural history was highly modern', and perhaps, Lene $\varnothing$ stermark-Johansen suggests, a 'provocation' to Jowett. Nevertheless, his understanding of Greek sculpture was also 'highly literary', based on readings of Homer and Pausanias (for a rather different view see Elizabeth Prettejohn, Chapter 12 in this volume). ${ }^{29}$

Pater's book Plato and Platonism (1893) began as a series of ten lectures for Oxford undergraduates studying Plato's Republic in 1891-2. Higgins compares Pater's and Jowett's versions of Plato as examples of 'an intense intellectual and ideological struggle for control over the Platonic canon' ${ }^{30}$ Plato was prominent in the Greats syllabus, and Jowett insisted that texts such as the Republic would equip his students to take their part in public life, as 'Platonic guardians for Britain and its empire' ${ }^{31}$ Stefano Evangelista argues that Pater's lectures have an ambivalent relationship with Jowett's version of Plato, and that Pater's impressionistic psychological reading of Plato undermined Jowett's emphasis on morality and 'linguistic and historical precision'. He also presented a more 'personal challenge' by making reference to 'Plato's frank discussions of homosexual desire, in which it is impossible not to read a pointer to Pater's own past dealings with Jowett's authority'. ${ }^{32}$ Pater's challenge to established interpretations of Plato is not just a dispute within the academy; in an introductory note to Plato and Platonism, he suggested that the lectures 
had been written for an undergraduate audience but were intended for all young students of philosophy. Even before the revised lectures appeared in volume form, some of the material was published in a monthly periodical, the Contemporary Review. In 1891 Pater wrote to the editor, Percy William Bunting, about the essay 'The Genius of Plato', saying that 'I have treated the subject in as popular a manner as I could' ${ }^{33}$ Pater surveys the history of Greek philosophy to give the uninitiated reader a context for Plato's ideas, and focuses on the form of the dialogue as a new mode of philosophical expression, comparable with more recent forms such as the essays of Montaigne. Lewis Campbell praised Pater's approach, arguing that his 'strong and earnest effort' to 'understand and realize Plato' by means of the 'historic method' was enhanced by 'the wealth of illustration readily afforded by his own full and fertile mind.... Not one century alone is present here. Much rather, all the centuries, the bloom of every civilization, flowers culled from every soil, are intertwined to form the delicately broidered framework. ${ }^{34}$

'Pater's Hellenic aestheticism was highly influential in the late Victorian period and his writing certainly enjoyed a wide appeal', writes T. D. Olverson. ${ }^{35} \mathrm{His}$ published lectures were 'popular' and 'very well received by critics'. ${ }^{36}$ His imaginative approach to ancient texts is exemplified in the essays on Demeter, Dionysus, and Hippolytus that he published in the Fortnightly Review and Macmillan's Magazine (posthumously collected as Greek Studies). Wright describes Pater's essay 'The Bacchanals' as 'a kind of paraphrase of Euripides' play, with which Pater takes very much the liberty that FitzGerald did with the poems of Omar Khayyám and Jami. Those scenes in old Thessaly are brought before us with extraordinary vividness' ${ }^{37}$ The reference to Edward FitzGerald, who also translated the Agamemnon in a 'Version-or Per-version' to be 'given away among Friends, who either knew nothing of the Original, or would be disposed to excuse the liberties taken with it', situates Pater in the context of playful and creative translation and adaptation in Victorian literature (see further Bénédicte Coste, Chapter 2 in this volume). ${ }^{38}$ 
Pater's desire to make Greek literature and philosophy available to readers outside the university may have been stimulated by his particular social and intellectual environment. From 1869 until 1885, in term time he lived in north Oxford with his sisters Clara and Hester (they spent the vacations in London), surrounded by academic households in which the campaign for the higher education of women gathered pace. Janet Howarth observes that there was support for the higher education of women among 'members of the university community'. After the statute that allowed dons to marry, the most prominent male supporters of lectures and then colleges for women were 'husbands and fathers of women who shared their interest in providing higher education for teachers and access to the world of learning for women with an aptitude for scholarship' ${ }^{39}$ The Paters belonged to a privileged society with a 'feminine counter-culture' in which 'the exceptional woman intellectual received encouragement' ${ }^{40}$ Many of the founders of the women's colleges that gradually gained acceptance and ultimately membership at Oxford and Cambridge were the sisters or wives of university men. Kali Israel comments that 'a high proportion of the names by which they survive are those of the men to whom they owed their own access to Oxford: Mrs. Arthur Johnson, Mrs. T. H. Green, Mrs. Humphry Ward, Mrs. Mandell Creighton, and, of course, Mrs. Mark Pattison'. ${ }^{41}$ Walter Pater was friends with Mary Ward and Emilia Pattison (later Lady Dilke), and wrote a letter of introduction for the American poet Louise Guiney so that she could gain access to the Bodleian library. ${ }^{42}$ Clara Pater was involved with the Committee of Oxford Lectures for Ladies and later with the Association for Promoting the Higher Education of Women in Oxford (1878). ${ }^{43}$ These organizations offered lectures and classes for women from 1873, including Latin and Greek texts and prose composition as well as ancient history. Clara Pater attended Nettleship's Latin class for women in 1874-5 with Matthew Arnold's niece Mary Ward (later famous as the novelist Mrs Humphry Ward) and Louise Creighton.

That Walter and Clara Pater were both tutors in Classics at Oxford colleges was remarkable in an era when, as Valerie Sanders points out, the 'theme of sisters prevented from studying with their brothers reverberates through nineteenth-century literature, with Latin the favourite symbol of 
male intellectual exclusiveness'. ${ }^{44}$ Somerville Hall (later Somerville College) opened in 1879 with twelve students. Clara Pater taught Greek, Latin, and German at Somerville, and was resident tutor in Classics from 1885 to 1894 (she resigned her tutorship shortly before her brother's death in 1894 and settled in London). As a college with resident tutors, Somerville acted as 'an extension of the tutorial system' for women students. ${ }^{45}$ For women's colleges, the greatest challenge was to provide intensive coaching so that students without ten years or more of learning grammar and syntax, or memorizing and translating set texts, could sit the same examinations as their brothers. Specialist tuition was also offered by dons from the men's colleges such as Nettleship (Horace) and Arthur Sidgwick (Demosthenes, Sophocles) ${ }^{46}$ L. M. Faithfull (later vice-principal of the Ladies' Department at King's College London) studied Latin with Nettleship. During this time, Somerville students achieved notable triumphs in classical studies: in 1888 Elizabeth Hodge's first in Mods, the preliminary classical examination, led to women being admitted to the Honour School of Literae Humaniores, in which she obtained a second in $1890 .{ }^{47}$ Emily Penrose (later principal of the College) was the first woman to achieve a first in Greats in 1892, although, as women were not yet full members of the university, she had to wait until 1920 to receive her degree. Penrose, who was the daughter of the archaeologist and director of the British School at Athens Francis Cranmer Penrose, chose to study archaeology as a Special Subject for Greats. From 1898 to 1900, Clara Pater taught at the Ladies' Department of King's College London, where she was lecturer in Greek and Latin. ${ }^{48} \mathrm{Her}$ most celebrated student was Virginia Stephen (later Woolf), with whom she read 'a considerable amount of Greek', including Sophocles' Antigone, Oedipus at Colonus, and half of the Trachiniae. ${ }^{49}$

Rather than attempting to compensate for their lack of experience in traditional pursuits such as prose and verse composition, women students often adopted new approaches based on emerging disciplines such as anthropology, archaeology, and comparative religion. Pater was an influential precursor for Jane Ellen Harrison, another scholar who combined college life (as tutor in Classics at Newnham College, Cambridge) with a place in the London literary world. In 'Greek Maenads, Victorian Spinsters', Yopie Prins contends that Pater's 'aestheticized and eroticized vision 
of ancient Greece' influenced the first generation of women who learned Greek at Cambridge, including Harrison and Katharine Bradley (who was later one of the poetic duo 'Michael Field'), as examples of the 'many women influenced by Pater in late Victorian England' ${ }^{50}$ Reforms at Cambridge in the late nineteenth century reflected the broadening of professional knowledge in classical studies by adding new options such as philosophy, history, archaeology, and comparative philology. Shanyn Fiske observes that Harrison took advantage of new opportunities to integrate 'archaeological, ethnological and sociological theories into Hellenic studies' despite any 'deficiencies in literary-linguistic knowledge'. Harrison's controversial theories about Greek art, religion, and myth left behind the textual tradition of 'pure' scholarship for a combination of scientific knowledge and imaginative insight. ${ }^{51}$ Harrison's Introductory Studies in Greek Art (1885) and her commentary on Pausanias in Mythology and Monuments of Ancient Athens (1890) develop themes notably similar to Pater's Oxford lectures. She shared Pater's fascination with myth, religious ritual, and the chthonic deities, and pursued these interests as one of the prominent group of 'Cambridge Ritualists' in the early years of the twentieth century.

Matthew Arnold, in his lecture 'Literature and Science' (1882), spoke of valuing the 'life and genius' of the Greeks and Romans, and 'what we get from them', instead of concentrating on 'so much vocabulary, so much grammar, so many portions of authors, in the Greek and Latin languages'. ${ }^{52}$ Although Turner states that Victorian professional classical scholars 'regarded their chief task as the establishment of authentic Greek and Latin texts, with the writing of interpretive studies or essays very much a secondary task', some very influential classicists focused on translating or interpreting classical texts. ${ }^{53}$ Prominent scholars like Richard Jebb, Benjamin Jowett, and Gilbert Murray were interested in the reception of ancient texts and participated in the dissemination of Greek literature to an audience outside the academy. They published translations and commentaries as well as textual scholarship; these included Jowett's The Dialogues of Plato translated into English with Analyses and Introductions (1871), his translation of Thucydides (1881), and of Aristotle's Politics (1885). E. F. Benson claims that Jowett's lack of pretensions to great scholarship as it was 
defined in his era was a strength, enabling him to produce 'readable English versions of exceedingly interesting books, which gave very fairly the sense of the original'. Since Jowett's own translations were not always accurate, he ensured that they were 'carefully revised by other scholars' (including the poet Swinburne, one of his students). ${ }^{54}$ Jebb translated The Characters of Theophrastus (1870), published a selection of Attic oratory (1876), edited the tragedies of Sophocles with text, critical notes, commentary, and translation (1883-96), and wrote an introduction to Homer (1887). Some classical scholars objected to the effect of such translations and commentaries on students: F. W. H. Myers complained that Greek and Latin had lost some of their 'educative power', since 'Sophocles is gradually depositing his invaluable obscurities as he filters through the brain of Professor Jebb'. ${ }^{55}$ In The Place of Greek in Education (1889), Gilbert Murray advocated the use of classical texts in translation, since the dissemination of 'Hellenism' does not depend on linguistic knowledge: 'It is quite possible for a man who cannot read a single page of Plato intelligently to acquire a tolerable proportion of the Greek spirit. ${ }^{56}$ Murray's verse translations of Greek plays from Euripides' Andromache (1900) to Aristophanes' The Knights (1956) were accompanied by comparative studies of Greek and English literature such as The Classical Tradition in Literature (1927).

Pater's essays on Greek literature, art, and religion contributed to the expansion of classical scholarship into new areas and communicated with a readership beyond the reach even of Jowett's and Jebb's works of translation and commentary. In his response to John Churton Collins's proposal to establish a School of English Literature at Oxford, Pater praised Oxford's 'abundant and disinterested devotion, in the face of much opposition, to Greek and Latin literature', arguing that the university's 'immense' influence on English literature was intrinsically linked with the study of antiquity. ${ }^{57} \mathrm{He}$ would not advocate the introduction of a School of English if it would 'throw into the background that study of classical literature which has proved so effective for the maintenance of what is excellent in our own', but proposed that classicists should expand and enliven their own discipline by studying the close connections between classical and modern culture, a comparative approach for which his own role in the development of Greats provided a model. 



\section{Abstract}

Pater contributed to the modernization of Classics at Oxford by introducing art and archaeology into the study of ancient literary, historical, and philosophical texts, and by examining myth and ritual. Pater's reading of texts, philosophical arguments, and historical examples from ancient Greece and Rome in relation to modern literature and philosophy exemplifies the comparative approach encouraged in Oxford Classics students. His wide reading and innovative approach did not always fit in with his role as a college lecturer preparing undergraduates for examinations, but helped to make him an influential precursor for scholars such as Jane Ellen Harrison. His sister Clara Pater also taught Classics at Oxford, and was involved with campaigns for the higher education of women. Pater sought to make Greek literature and philosophy available to readers outside the university by publishing versions of his lectures in popular periodicals and books.

Keywords

classical scholarship, Latin, Greek, Oxford University, women's higher education

\section{Notes}

${ }^{1}$ Christopher Stray, Classics Transformed: Schools, Universities, and Society in England, 1830-1960 (Oxford, 1998), pp. 12, 117.

${ }^{2}$ Richard Jenkyns, 'The Beginnings of Greats, 1800-1872: Classical Studies', in The History of the University of Oxford, VI. Nineteenth-Century Oxford, Part 1, ed. M. G. Brock and M. C. Curthoys (Oxford, 1997), pp. 513-14. See also W. H. Walsh, ‘The Zenith of Greats’ (pp. 311-26) and Richard Jenkyns, 'Classical Studies, 1872-1914' (pp. 327-31), in The History of the University of Oxford, VII. Nineteenth-Century Oxford, Part 2, ed. M. G. Brock and M. C. Curthoys (Oxford, 2000) 
${ }^{3}$ University of Oxford, New Examination Statutes: Abstracts of their Principal Provisions with a Catalogue of Books, Either Expressly Mentioned, or Treating of the Subjects Required (Oxford, 1851), pp. 2-3.

${ }^{4}$ New Examination Statutes, p. 7.

${ }^{5}$ New Examination Statutes, p. 9.

${ }^{6}$ New Examination Statutes, p. 4.

${ }^{7}$ Edmund Gosse, ‘Walter Pater: A Portrait’, Contemporary Review, 66 (1894), 795-810 (799).

${ }^{8}$ Frank M. Turner, The Greek Heritage in Victorian Britain (New Haven, 1981), p. 406.

${ }^{9}$ Gosse, 'Walter Pater', p. 799.

${ }^{10}$ E. F. Benson, As We Were: A Victorian Peep-Show (1930), p. 148.

${ }^{11}$ Letter to [Jowett’s biographer] Lewis Campbell, 6 May 1894: Letters, p. 154.

${ }^{12}$ Thomas Wright, The Life of Walter Pater (1907), I, p. 197.

${ }^{13}$ Helen H. Law, ‘Pater’s Use of Greek Quotations’, MLN 58: 8 (1943), 575-85 (585).

${ }^{14}$ Housman's inaugural lecture at Cambridge (1911) contrasted Cambridge’s ‘scholarship with no nonsense about it' with Oxford's misguided inclusion of literary appreciation in classical studies: A. E. Housman, The Confines of Criticism: The Cambridge Inaugural 1911, ed. J. Carter (Cambridge, 1969), pp. 25-6. See also Stray, Classics Transformed, pp. 121-4, and A. E. Housman: Classical Scholar, ed. David Butterfield and Christopher Stray (2009). Housman’s supremacy in the traditional field of textual criticism might be considered a limitation when contrasted with the opportunities opening up in classical studies at the time: see J. P. Sullivan, 'The Leading Classic of His Generation', in A. E. Housman: A Collection of Critical Essays, ed. Christopher Ricks (Englewood Cliffs, NJ, 1968), pp. 146-62.

${ }^{15}$ A. C. Benson, Walter Pater (1906), pp. 22-3.

${ }^{16}$ Stray, Classics Transformed, p. 122.

${ }^{17}$ Henry Nettleship, Lectures and Essays on Subjects Connected with Latin Literature and Scholarship (Oxford, 1885), pp. 1-2. See also S. J. Harrison, 'Henry Nettleship and the Beginning 
of Modern Latin Studies', in Oxford Classics: Teaching and Learning, 1800-2000, ed. Christopher Stray (2007), pp. 107-16.

${ }^{18}$ Gosse, ‘Walter Pater’, p. 804.

${ }^{19}$ William Shuter, 'Pater, Wilde, Douglas and the Impact of "Greats” <thin>', English Literature in Transition, 1880-1920, 46: 3 (2003), 250-78 (250-1).

${ }^{20}$ Lesley Higgins, ‘Essaying “W. H. Pater Esq.”: New Perspectives on the Tutor / Student Relationship Between Pater and Hopkins', in Pater in the 1990s, ed. Laurel Brake and Ian Small (1991), p. 81. The essays appear in The Collected Works of Gerard Manley Hopkins, IV. Oxford Essays and Notes 1863-1868, ed. Lesley Higgins (Oxford, 2006), pp. 218-34. This volume includes ‘Notes on Hopkins’s Tutors’, pp. 50-65.

${ }^{21}$ Benson, Walter Pater, pp. 24-5.

${ }^{22}$ Wright, Life, I, p. 197.

${ }^{23}$ Benson, Walter Pater, p. 20.

${ }^{24}$ Shuter, 'Pater, Wilde, Douglas’, p. 252.

${ }^{25}$ Shuter, 'Pater, Wilde, Douglas', pp. 250-1. For example, books 1, 5, and 6 of Pausanias were set texts for a Greek History 'Special Subject', and in 1878 Pater gave lectures on those books in a series on the history of Greek art; the lectures 'evidently formed the basis of the two essays that Pater published in the Fortnightly Review in 1880'. Pater also drew on Pausanias for an account of the Eleusinian mysteries, which informed his lecture on 'Demeter and Persephone', given at the Birmingham and Midland Institute on 29 November 1875 and later published in the Fortnightly Review.

${ }^{26}$ Shuter, 'Pater, Wilde, Douglas’, pp. 254-5. Iain Ross notes that one of Oscar Wilde’s Mods examinations included a discussion of the Odyssey, Aeschylus, Shakespeare, Walt Whitman, and Aristotle’s Poetics (Iain Ross, Oscar Wilde and Ancient Greece (Cambridge, 2012), p. 37). Ross reproduces the Literae Humaniores syllabus for 1874 in appendix B (pp. 197-9).

${ }^{27}$ William Shuter, Rereading Walter Pater (Cambridge, 1997), p. 80. 
${ }^{28}$ Shuter, 'Pater, Wilde, Douglas’, p. 251.

${ }^{29}$ Lene Østermark-Johansen, Walter Pater and the Language of Sculpture (Farnham, 2011), p. 218.

${ }^{30}$ Lesley Higgins, 'Jowett and Pater: Trafficking in Platonic Wares', Victorian Studies, 37 (1993), 445. Edmund Gosse claims that Jowett was impressed by Pater’s book: his ‘cordially’ congratulatory response to Plato and Platonism ended the 'complete estrangement of sympathy' that had followed Pater's involvement with the Balliol undergraduate W. M. Hardinge, and led Jowett to block Pater’s advancement within the university: Gosse, ‘Walter Pater’, p. 799.

${ }^{31}$ Stray, Classics Transformed, p. 122.

${ }^{32}$ Stefano Evangelista, 'Walter Pater’s Teaching in Oxford: Classics and Aestheticism', in Stray, Oxford Classics, pp. 72-4.

${ }^{33}$ Letters, p. 124. The essay was printed in the Contemporary Review, 61 (February 1892), 249-61, and later revised and published as chapter 6 of Plato and Platonism.

${ }^{34}$ Lewis Campbell, 'Pater’s Plato and Platonism', Classical Review, 7 (1893), 263-6, repr. in Critical Heritage, pp. 270-7 (270-1).

${ }^{35}$ T. D. Olverson, Women Writers and the Dark Side of Late-Victorian Hellenism (Basingstoke, 2010), p. 131.

${ }^{36}$ Carolyn Williams, Transfigured World: Walter Pater's Aesthetic Historicism (Ithaca, NY, 1989), p. 235.

${ }^{37}$ Wright, Life, II, pp. 1-3.

${ }^{38}$ Edward FitzGerald, Agamemnon: A Tragedy, Taken from Aeschylus (privately printed 1865; published anonymously 1876).

${ }^{39}$ Janet Howarth, 'Women', in The History of the University of Oxford, VIII. The Twentieth Century, ed. Brian Harrison (Oxford, 1994), pp. 346-7.

${ }^{40}$ Janet Howarth, ‘<thin> “In Oxford but . . . Not of Oxford”: The Women’s Colleges’, in Brock and Curthoys, History of the University of Oxford, VII, pp. 238-42.

${ }^{41}$ Kali Israel, Names and Stories: Emilia Dilke and Victorian Culture (New York, 1999), pp. 94-5. 
${ }^{42}$ Letters, p. 111.

${ }^{43}$ Laurel Brake, 'Pater, Clara Ann (bap. 1841, d. 1910)', Oxford Dictionary of National Biography, Oxford University Press, 2004 ( http://www.oxforddnb.com.catalogue.ulrls.lon.ac.uk/view/article/48505, accessed 31 July 2015).

${ }^{44}$ Valerie Sanders, The Brother-Sister Culture in Nineteenth-Century Literature: From Austen to Woolf (Basingstoke, 2002), p. 19.

${ }^{45}$ Vera Brittain, The Women at Oxford: A Fragment of History (1960), pp. 88-9.

${ }^{46}$ Muriel St Clare Byrne and Catherine Hope Mansfield, Somerville College, 1879-1921 (1922), p. 60.

${ }^{47}$ Pauline Adams, Somerville for Women: An Oxford College, 1879-1993 (Oxford, 1996), p. 39.

${ }^{48}$ See Anna Snaith and Christine Kenyon-Jones, 'Tilting at Universities: Virginia Woolf at King’s College London', Woolf Studies Annual, 16 (2010), 1-44.

${ }^{49}$ Henry Malley, ‘A Rediscovered Eulogy: Virginia Woolf’s “Miss Janet Case: Classical Scholar and Teacher" <thin>’, Twentieth-Century Literature, 28 (1982), 290. Clara Pater is said to have provided the inspiration for tutors in Woolf's fiction—Lucy Craddock, Kitty Malone's tutor in The Years (1937) and Julia Craye (sister to a famous archaeologist) in ‘Slater’s Pins Have No Points’ (1928).

${ }^{50}$ Yopie Prins, ‘Greek Maenads, Victorian Spinsters’, in Victorian Sexual Dissidence, ed. Richard Dellamora (Chicago, 1999), pp. 43-81 (44-6).

${ }^{51}$ Shanyn Fiske, Heretical Hellenism: Women Writers, Ancient Greece, and the Victorian Popular Imagination (Athens, OH, 2008), pp. 150-1.

${ }^{52}$ The Complete Prose Works of Matthew Arnold, ed. R. H. Super, X. Philistinism in England and America (Ann Arbor, MI, 1974), pp. 57-8.

${ }^{53}$ Frank M. Turner, Contesting Cultural Authority: Essays in Victorian Intellectual Life (Cambridge, 1993), p. 286.

${ }^{54}$ Benson, As We Were, p. 150. 
55 'English at the Universities.-IV’, Pall Mall Gazette (27 Nov. 1886), 2.

${ }^{56}$ Gilbert Murray, The Place of Greek in Education, An Inaugural Lecture (Glasgow, 1889), quoted in Duncan Wilson, Gilbert Murray, OM, 1866-1957 (Oxford, 1987), p. 44. It was in 1894, while Murray was professor of Greek, that Pater was awarded an honorary doctorate (LLD) by the University of Glasgow.

${ }^{57}$ In 1886-7 the Pall Mall Gazette asked a number of intellectuals (including T. H. Huxley, J. A. Froude, Matthew Arnold, William Morris, F. W. H. Myers, and Pater) to comment on whether it was desirable for universities to provide systematic instruction in English literature, whether any distinction should be made between instruction in literature and in philology, and whether the study of English should be 'indissolubly associated with the study of ancient Classical literature?'; see The Complete Prose Works of Matthew Arnold, ed. R. H. Super, XI. The Last Word (Ann Arbor, MI, 1977), pp. 500-1. Pater's article is reprinted in Letters, pp. 68-9. For a full account of the episode, its context, and wider significance, see D. J. Palmer, The Rise of English Studies: An Account of the Study of English Language and Literature from Its Origin to the Making of the Oxford English School (1965), ch. 6, 'John Churton Collins and the Attack on Oxford', pp. 78-103. 